\title{
NUOSTATOS KAIP SOCIALINIO DARBUOTOJO \\ PROFESINĖS VEIKLOS MOTYVACIJĄ SKATINANTIS VEIKSNYS
}

\author{
Vanda Kavaliauskienè, Edita Nikolajenko \\ Klaipédos universitetas
}

\begin{abstract}
Anotacija
Šio straipsnio dèmesio centre - socialinio darbuotojo, kaip labiausiai kvalifikuoto socialinio darbo profesijos atstovo, asmenybė. Tiriamos socialinio darbuotojo nuostatos dẻl savo gebejjimų ir aplinkos, kaip veiksniai, galintys stiprinti profesinès veiklos motyvaciją. Tyrimas grindžiamas motyvacijos sistemų teorijos efektyvaus funkcionavimo koncepcija. Taikomas interviu metodas. Tiriamos socialinio darbuotojo nuostatos dèl savo gebejjimų grindžiamos pagrindiniais socialinio darbo proceso komponentais. Tirti socialinių darbuotojų nuostatas dẻl aplinkos taikomas konstruktas, atskleidžiantis socialinėms profesijoms būdingus esminius nuo organizacijos priklausomus veiksnius. Tyrimo rezultatai išryškina tirtus socialinių darbuotojų nuostatų parametrus ir atskleidžia vyraujančius socialinių darbuotojų profesinio funkcionavimo modelius, kurie rodo socialinių darbuotojų profesinės veiklos motyvacijos lygmeni.

PAGRINDINIAI ŽODŽIAI: socialinis darbas, profesinès veiklos motyvacija, nuostatos dèl savo gebẻjimų ir aplinkos.
\end{abstract}

\begin{abstract}
The focus of this article is on the personality of a social worker as most qualified representative of the profession. The task of the article is to explore social worker's personal agency and context beliefs as a factor to increase the motivation of social worker's professional activity. The methodological basis of the research is the Concept of Effective Functioning (Motivational Systems Theory, Ford, 1992). The talk - interview was used to gain factual information about social worker's capability beliefs related to the main elements of problem solving process. To explore social worker's context beliefs, a construct embracing essential factors characteristic to social organizations was made. The research provide information about the mentioned parameters of the beliefs and reveal the dominating patterns of social workers' professional functioning indicating the level of their motivation.

KEY WORDS: social work, motivation of professional activity; personal agency and context beliefs.
\end{abstract}

\section{Ivadas}

Socialinis darbas, jo sritys, turinys, profesinès veiklos funkcijos yra veikiami besikeičiančių socialinių, ekonominių, politinių ir kultūrinių sąlygų. Socialinio darbo profesija, jos ịgyvendinimo uždaviniai ir strategija neišvengiamai siejami su socialiniu darbuotoju - labiausiai kvalifikuotu savo profesijos atstovu. Socialinio darbo profesionalizacijos procese ryškèja žmogiškojo veiksnio svarba. Nūdienos Lietuvos socialinio darbo kokybès aktualijos skatina iš naujo pažvelgti, pažinti ir suprasti profesijos subjekto funkcionavimo, igyjančio vienoki ar kitoki profesinès 
veiklos braižą, skatinantị tam tikru būdu reaguoti ị daiktus, žmones, ịvykius ir darantị įtaką darbinei profesijos subjekto veiklai, šaltinius.

Nuolat kintanti socialinio darbuotojo profesinè realybè, veikiama žinių, igūdžių ir vertybių kaitos, turi tendenciją transformuotis ị profesionalią, kūrybišką ir socialinių permainų aktualijas atliepiančią profesinę veiklą. Socialinio darbuotojo veiklos ypatumus, pastangas, jo aktyvumą atskleidžia motyvacija, leidžianti traktuoti profesijos subjektą kaip asmenybę, kuriančią ir kaupiančią savo asmeninę, unikalią patirtị. Kai klausiame, kodèl socialinis darbuotojas skuba padèti žmogui arba delsia, elgiasi vienaip ar kitaip, turime pažvelgti ị motyvus.

Socialinio darbo srities mokslininkai nemažai dèmesio skiria socialinio darbuotojo motyvacijos funkcijai. Tai matyti iš daugelio autorių mokslinių publikacijų (Johnson, 2003; Šinkūnienė, Katkovienè, 2010; Dirgèlienė, 2010; Kiaunyte, 2010; Dromantaitè, 2012; Kavaliauskienè, 2008; 2010; 2013 ir kt.).

Pripažįstama, kad socialinio darbuotojo sèkmingai profesinei veiklai būtinos tinkamos objektyvios (išorinès) aplinkybės (darbo sąlygos, darbo organizavimas, darbuotojų tarpusavio santykiai ir santykiai su vadovais) ir subjektyviosios (vidinės) aplinkybės (Jovaiša, 2007; Laužackas, 2005; Kavaliauskienė, 2013). Vidiniai socialinių darbuotojų motyvacijos veiksniai glaudžiai sąveikauja su išoriniais profesinès veiklos motyvacijos veiksniais. Kiekvienos profesijos darbuotojų elgseną skatina ịvairios tarpusavyje susijusios vidinès ir išorinès jẻgos. Per ilgesnị ar trumpesnị laiką ịgyjant patirties, žinių, įspūdžių, igūdžių, ịpročių, požiūrių, formuojasi nuostatos - jausmai, pagrịsti įsitikinimais, kurie reikšmingi profesinei veiklai (Myers, 2008). Daugelio autorių (Garfield, 1986; Furnham, 1992; Johnson, 2001; Covey, 2007; Jovaiša, 1999, Kavaliauskienè, 2013) nuomone, žmogaus asmenybès savybès, nuostatos kreipia jo mąstymą, poelgius, veiklą tam tikra kryptimi.

Nūdienos Lietuvos socialinio darbo kokybès aktualijos skatina iš naujo pažvelgti ị socialinio darbuotojo motyvaciją, kaip procesą, iki šiol dažnai esantị tarp teorinių ir praktinių plotmių. Jų optimizavimo tikslas - pagerinti socialinio darbuotojo funkcionavimą, diegti profesinę kultūrą, stiprinti profesinị tapatumą, ugdyti gebejimą pažinti, suprasti nuolat besikeičiančią socialinę tikrovę, sudaryti kiekvienam socialiniam darbuotojui galimybę tapti pripažintu profesionalu teikiant kokybiškas socialines paslaugas ịvairių lygių klientams.

Ieškant socialinio darbuotojo efektyvaus profesinio funkcionavimo šaltinių, vertinga aiškintis, kaip žmogus žiūri ị savo veiklą, kokios yra jo nuostatos dèl savo gebèjimų ir aplinkos, ar jis mano / tiki turịs gebejimų ir galimybių vykdyti profesinę veiklą, ar tai žadina šios profesijos subjekto energiją, stimuliuoja jo aktyvumą, norą tapti pripažintu profesionalu.

Atsižvelgiant ị šias aplinkybes, šio tyrimo objektas - socialinių darbuotojų nuostatos, kaip profesinès veiklos motyvacijos šaltinis. 
Tikslas: atskleisti socialinių darbuotojų nuostatas (dèl savo gebejjimų ir aplinkos), kaip profesinès veiklos motyvacijos šaltinị.

Tyrimo metodai: mokslinès literatūros analizè, kokybinis tyrimas (turinio analizè), aprašomoji interpretacija.

\section{Tyrimo metodika, eiga}

Remiantis motyvacijos sistemų teorijos efektyvaus funkcionavimo koncepcija (Ford, 1992), asmenybės bruožai lemia tai, kaip žmogus atlieka savo darbą. Šiems bruožams susidaryti didelę reikšmę turi nuostata dèl savo gebejjimų ir aplinkos, pasireiškianti tikejjimu savo gebejjimais ir aplinka. Autoriaus teigimu, labai svarbu, kad žmogus tikètų tuo, kad jis turi tokių gebẻjimų ir galimybių. Tiriant socialinių darbuotojų nuostatas dèl savo gebejjimų ir aplinkos taikytas iš dalies struktūruotas interviu, pateikiant klausimų sąrašą.

Šio tyrimo pamatas - motyvacijos sistemų teorijos efektyvaus funkcionavimo koncepcija (Ford, 1992), grindžiama efektyvaus funkcionavimo modeliais, kurie susiję su nuostatomis dèl savo gebẻjimų ir aplinkos (žr. 1 lentelę).

1 lentelè. Modelių, susijusių su nuostata dèl savo gebejjimų ir aplinkos, taksonomija

\begin{tabular}{|l|l|l|l|}
\hline \multirow{2}{*}{$\begin{array}{c}\text { Nuostata dèl } \\
\text { aplinkos }\end{array}$} & \multicolumn{3}{|c|}{ Nuostata dėl savo gebejimų ir ją atitinkantis modelis } \\
\cline { 2 - 4 } & Stipri & Kintanti & Silpna \\
\hline Teigiama & Tvirtos (tvirtas) & Vidutiniška (kuklus) & Netvirta (trapus) \\
\hline Neutrali (kintama) & Tvirtos (atkaklus) & $\begin{array}{l}\text { Vidutiniška (silpnas } \\
{[\text { pažeidžiamas]) }}\end{array}$ & Netvirta (abejojantis) \\
\hline Neigiama & $\begin{array}{l}\text { Abejojama (susitai- } \\
\text { kantis) arba priešina- } \\
\text { masi (priešiškas) }\end{array}$ & $\begin{array}{l}\text { Vidutiniška } \\
\text { (nusivylęs) }\end{array}$ & Silpna (beviltiškas) \\
\hline
\end{tabular}

Anot M. E. Fordo (1992), nuostatos dèl savo gebejjimų ir aplinkos suponuoja tam tikrus asmens veiksnumo bruožus, motyvacijos modeli, kuris koreliuoja su tikslo siekiu, jo turiniu, profesinès veiklos kokybe, taip pat su savojo „A ̌`“ interpretacija.

Atsižvelgdamas ị tai, minètas autorius pateikia 10 asmens motyvacijos charakteristikų modelių:

- Tvirto charakterio asmens motyvacijos modelis įvardytas kaip tvirtas, kai asmeniui būdingi tvirti tikslai ir požiūriai.

- Kuklaus charakterio asmens motyvacijos modelis įvardytas kaip kuklus, nes jis vidutiniškai vertina savo gebejjimus.

- Trapaus charakterio asmens motyvacijos modelis ịvardytas kaip trapus, nes asmuo linkęs save nuvertinti, sumenkinti, kaltinti save labiau nei aplinką, kurioje dirba. 
- Atkaklaus charakterio asmens motyvacijos modelis ịvardytas kaip atkaklus, nes asmuo išlieka tvirtas ir stiprus, susidūręs su problemomis ir kliūtimis.

- Silpno (pažeidžiamo) asmens motyvacijos modelis įvardytas kaip silpnas, nes svyruojanti asmens motyvacija, nerimas ir prieštaringi jausmai dèl palankių / nepalankių rezultatų trukdo siekti tikslo.

- Abejojančio asmens motyvacijos modelis ịvardytas kaip abejojantis, nes asmuo nepakankamai pasitiki savimi, esant net sẻkmès galimybei.

- Susitaikyti linkusio asmens motyvacijos modelis ịvardytas kaip susitaikantis - jis tyliai ištveria sunkumus.

- Priešiško asmens motyvacijos modelis įvardytas kaip priešiškas, nes asmuo linkęs reikšti kylantị susierzinimą ir priešiškumą.

- Nusivilti linkusio asmens motyvacijos modelis įvardytas kaip nusivylęs, nes asmuo dažnai būna prislègtas, nors ir išlaiko šiek tiek pasitikẻjimo, turi vilties.

- Vilti praradusio asmens motyvacijos modelis įvardytas kaip beviltiškas, nes asmuo netiki sèkme ir jos nesitiki.

Tiriant socialinio darbuotojo nuostatas dẻl savo gebẻjimų atsižvelgta ị pagrindinius socialinio darbo proceso komponentus (Johnson, 2001), suvokiamus kaip galinčius lemti vienokị ar kitokị individų ir socialinių sistemų socialinị funkcionavimą. Tirtos socialinių darbuotojų nuostatos, susijusios su poreikio, kaip paslaugos klientui teikimo, nustatymo; paslaugos teikimo klientui planavimo; paslaugu teikimo klientui; teikiamu paslaugu vertinimo, gebejjimais (žr. 2 pav.).

Tirtas socialinių darbuotojų nuostatos dèl aplinkos konstruktas (sudarytas remiantis V. Kavaliauskienès atlikto tyrimo rezultatais, žr. Kavaliauskienė, 2013; Gustaitienè, Pranskevičienė, Bukšnytè-Marmienè, ir kt., 2014; Šorytė, Pajarskienè, 2014) atskleidžia socialinèms profesijoms būdingus esminius nuo organizacijos priklausomus darbuotojo gerovès veiksnius. Atsižvelgiant $i$ tyrimo tikslą ir turinį, siekta atrinkti respondentus, kurie nagrinejjamuoju klausimu turi žinių ir patirties. Tiriamieji - 16 socialinių darbuotojų, dirbančių įvairiose socialinėse institucijose: socialinių paslaugų, šeimos ir vaiko gerovès centruose, nakvynès namuose, „Caritas" globos namuose, neigaliujų ir specialiojo ugdymo centruose.

\section{Tyrimo rezultatai ir jų interpretacija}

Neabejojama, kad socialinių darbuotojų darbo procesui reikia gebejimų - tai svarbi sẻkmingos socialinio darbuotojo profesinès veiklos sudedamoji. Atliktas tyrimas, siekiant nustatyti socialinių darbuotojų nuostatas, susijusias su socialinio 
darbo procesų etapais (2 lenteleje pažymèta A, B, C, D raidėmis) ir esminiais šių etapų žingsniais (2 lentelèje pažymèta arabiškais skaitmenimis) atskleidžia tiriamujų subjektyvaus požiūrio ị tiriamus aspektus vaizdą (žr. 2 lentelę).

2 lentelè. Socialinio darbuotojo nuostatos dèl savo gebèjimu

\begin{tabular}{|c|c|c|c|c|}
\hline & \multirow[t]{2}{*}{ Gebèjimai } & \multicolumn{3}{|c|}{ Nuostatos } \\
\hline & & Tvirtos & Vidutinès & Silpnos \\
\hline A & Poreikio, kaip paslaugos klientui teikimo, nustatymas & & & \\
\hline 1. & Suvokti kliento problemos esmę & 11 & 5 & 0 \\
\hline 2. & Suprasti kliento paslaugos poreiki & 14 & 2 & 0 \\
\hline 3. & $\begin{array}{l}\text { Nustatyti šaltinius, kurie gali patenkinti kliento } \\
\text { poreiki }\end{array}$ & 12 & 4 & 0 \\
\hline 4. & $\begin{array}{l}\text { Ivertinti ịvvairių išteklių galimybes patenkinti kliento } \\
\text { poreikị }\end{array}$ & 11 & 5 & 0 \\
\hline 5. & Suprasti, kas trukdo patenkinti kliento poreiki & 11 & 5 & 0 \\
\hline B & Planuoti paslaugos teikimą klientui & & & \\
\hline 6. & Nustatyti paslaugos teikimo tikslus ir uždavinius & 14 & 2 & 0 \\
\hline 7. & Apibrèžti ịvairių išteklių naudingumą & 10 & 6 & 0 \\
\hline 8. & $\begin{array}{l}\text { Priimti profesionalius sprendimus ir pasirinkti } \\
\text { tinkamiausią alternatyvą }\end{array}$ & 14 & 2 & 0 \\
\hline 9. & Sukurti pagalbos teikimo modeli & 8 & 7 & 1 \\
\hline 10. & Ivertinti galimybę pasiekti tikslus & 6 & 10 & 0 \\
\hline $\mathrm{C}$ & Paslaugų teikimas klientui & & & \\
\hline 11. & $\begin{array}{l}\text { Išmanyti paslaugų teikimo sistemą ir suvokti } \\
\text { aplinką, kurioje gyvena ir funkcionuoja klientas }\end{array}$ & 13 & 3 & 0 \\
\hline 12. & Atpažinti krizinę situaciją & 15 & 1 & 0 \\
\hline 13. & $\begin{array}{l}\text { Teisingai naudoti žinias / informacija, gaunamą iš } \\
\text { ivvairių šaltinių, matyti visus situacijos aspektus }\end{array}$ & 13 & 3 & 0 \\
\hline 14. & $\begin{array}{l}\text { Naudotis prieinamais ištekliais ir derinti ịvairias } \\
\text { veiklos rūšis }\end{array}$ & 12 & 3 & 1 \\
\hline 15. & Igalinti klientus keistis patiems ir keisti aplinką & 9 & 7 & 0 \\
\hline $\mathrm{D}$ & Teikiamų paslaugų vertinimas & & & \\
\hline 16. & $\begin{array}{l}\text { Ivertinti paslaugos teikimo būdo pranašumus ir } \\
\text { trūkumus }\end{array}$ & 11 & 5 & 0 \\
\hline 17. & İsivertinti asmeninius pranašumus ir trūkumus & 12 & 3 & 1 \\
\hline 18. & $\begin{array}{l}\text { Ivertinti etinius klausimus, kurių kyla teikiant } \\
\text { paslaugąs }\end{array}$ & 11 & 4 & 1 \\
\hline 19. & İvertinti savo profesinị augimą & 10 & 5 & 1 \\
\hline 20. & $\begin{array}{l}\text { Apibendrinti gautą patirtị ir teiktų paslaugų } \\
\text { naudingumą }\end{array}$ & 14 & 1 & 1 \\
\hline
\end{tabular}


Tyrimo rezultatai atskleide, kad didžioji dauguma respondentų nuostatas (tvirtas) dèl savo gebejjimų grindžia produktyviu darbu ir savirealizacija bei tiki turị reikiamų gebėjimų sèkmingai dirbti socialini darbą. Kaip produktyvios veiklos veiksnius respondentai išskiria instrumentinius socialinio darbuotojo gebejimus („Esu pajègi ịvertinti kliento poreikius, jo aplinką, suprasti kliūtis, trukdžius“ (5); „Manau, kad gebu profesionaliai įvertinti kliento problemas, paslaugos poreikį“ (2); ,Siekdama padèti klientui stengiuosi surinkti kuo daugiau informacijos, kuri turi įtakos kliento situacijai ir priimti tinkamus sprendimus; „Dedu daug pastangų, siekdama išnaudoti atsiradusias galimybes padèti klientui“ (3); „Gebu pilnavertiškai dirbti socialinį darbą ir tinkamai atstovauti klientų interesams“ (14) „Pasitikiu savo gebejjimais, atiduodu visas jègas darbui ir jaučiu, kad galiu veikti produktyviai“ (2); „Esu jautri, empatiška, sąžininga, pareiginga, kūrybinga“ (7); „Esu labai empatiška, žingeidi, komunikabili“ (15); „Jaučiu poreiki padèti kitam žmogui - tai ir yra socialinio darbo esmë“ (2). Daugelis socialinių darbuotojų akcentuoja savo asmenybės savybes kaip adekvačias socialinio darbo profesijai. Socialiniam darbuotojui, kuris siekia tikslingo pokyčio kliento situacijoje, būtini atitinkami profesiniai gebejjimai.

Anot V. A. Samoilovos (2007), norint dirbti socialinị darbą, reikia turèti ypatingų socialinio darbuotojo gebėjimų, tarp kurių svarbią vietą užima refleksija ir veiksmingas savo veiklos reguliavimas, esant probleminei situacijai. Tokių atvejų socialinio darbo praktikoje pasitaiko gana dažnai. Kartais socialiniai darbuotojai nẻra užtikrinti turị būtinų gebejjimų: „Būna momentų ar ịvykių, kai pradedi abejoti savo gebèjimais“ (11); „Sudètingesnèmis situacijomis būna sunku ịveikti stresą, tinkamai reguliuoti savo veiklą“ (10).

Nors didžiosios dalies respondentų nuostatos dèl savo gebėjimų vykdyti socialinio darbo funkcijas yra tvirtos ir teigiamos, dèl tam tikrų socialiam darbo procesui būtinų gebėjimų dalis respondentų nèra užtikrinti (kintančios nuostatos). Tai gebèjimai, susiję su paslaugos teikimo klientui planavimu (ịvertinti galimybę pasiekti tikslus [10 respondentų]; sukurti pagalbos teikimo modeli [7 respondentai]; apibrěžti įvairių išteklių naudingumą [6 respondentai]; suteikti klientui paslaugas - igalinti klientus siekti pokyčių keisti save ir aplinką [7 respondentai]). Šio tyrimo rezultatai atskleidè, kad socialiniai darbuotojai planavimą laiko gana sudètingu viso proceso komponentu. Tai tvirtina ir socialinio darbo vadovèlinès tiesos. Anot L. S. Jonhson, „šis socialinio darbo proceso etapas iš pirmo žvilgsnio atrodo aiškus ir paprastas, bet taip nèra (...). Planavimas apima problemos apibrèžimą ir jos sprendimo paiešką, jis susieja tikslą su veiksmu. Planavimo kontekstas yra intervencija į žmonių ir socialinių sistemų sąveiką. Galutinis tikslas - planuotas pasikeitimas. (...) dèl žmogaus prigimties ir socialinès situacijos sudètingumo neį- 
manoma tiksliai numatyti plano išdavų“ (Johnson, 2001, p. 249). Šiame kontekste socialinių darbuotojų tvirtinimas, kad „profesionalumo pamatas - teorinès žinios“" (4), ,dar trūksta žinių, platesnio požiūrio ị socialinį darbą“" (1) pagrindžia šio socialinio darbo etapo reikšmingumą ir sudètingumą.

Socialinio darbuotojo nuostatos dèl savo gebejimų glaudžiai sąveikauja su nuostatomis dèl savo darbinès aplinkos ir sudaro vientisą profesinès motyvacijos charakteristiką. Tirtų socialinių darbuotojų nuostatų dẻl aplinkos rezultatai pateikti 3 lentelèje.

3 lentelè. Socialinio darbuotojo nuostatos dèl aplinkos profesinès veiklos kontekste

\begin{tabular}{|c|c|c|c|}
\hline \multirow[t]{2}{*}{ Profesinès aplinkos elementai } & \multicolumn{3}{|c|}{ Nuostatos } \\
\hline & Tvirtos & Vidutinès & Silpnos \\
\hline Objektyvus, teisingas ir geranoriškas vadovavimas & 10 & 5 & 1 \\
\hline $\begin{array}{l}\text { Rūpinimasis organizacijos tikslais, komandiniu darbu ir } \\
\text { jos tobulinimo galimybemis }\end{array}$ & 11 & 4 & 1 \\
\hline $\begin{array}{l}\text { Domejjimasis darbuotojo profesinio ir asmeninio } \\
\text { tobulëjimo poreikiais, galimybių padèti darbuotojams } \\
\text { igyvendinti savo siekius paieška }\end{array}$ & 9 & 5 & 2 \\
\hline $\begin{array}{l}\text { Konstruktyvios grižtamosios informacijos, sutelktos i } \\
\text { svarbiausius sèkmingo užduoties atlikimo veiksnius, } \\
\text { teikimas }\end{array}$ & 7 & 7 & 2 \\
\hline $\begin{array}{l}\text { Galimybe mokytis ir tobulèti (seminarai, konferencijos, } \\
\text { kvalifikacijos tobulinimo kursai, mokymai, dalijimasis } \\
\text { patirtimi ir kt.) }\end{array}$ & 9 & 7 & 0 \\
\hline $\begin{array}{l}\text { Galimybė būti pripažintam ir palaikomam (ne tik kaip } \\
\text { darbuotojui, bet ir kaip asmeniui) }\end{array}$ & 9 & 3 & 4 \\
\hline $\begin{array}{l}\text { Palanki darbo atmosfera, emocijų ir nuotaikų valdymas, } \\
\text { draugiški kolegų tarpusavio santykiai }\end{array}$ & 10 & 4 & 2 \\
\hline $\begin{array}{l}\text { Objektyvūs veiklos rezultatų vertinimo, skatinimo ir } \\
\text { atlyginimo būdai }\end{array}$ & 9 & 4 & 3 \\
\hline $\begin{array}{l}\text { Tinkamas apdovanojimų (garbès raštu, pagyrimų, } \\
\text { atminimo dovanų ir kt.) skyrimas }\end{array}$ & 7 & 5 & 4 \\
\hline Galimybè siekti karjeros & 5 & 5 & 6 \\
\hline $\begin{array}{l}\text { Draugiški santykiai su kolegomis ne darbo metu (šventès, } \\
\text { gimtadieniai, išvykos ir kt.) }\end{array}$ & 11 & 4 & 1 \\
\hline
\end{tabular}

Kaip rodo tyrimo rezultatai, socialinių darbuotojų nuostatos dèl darbo aplinkos nèra vienareikšmiškos. Dėl kai kurių profesinės aplinkos elementų daugelis socialinių darbuotojų turi tvirtas teigiamas nuostatas. Tai: rūpinamasis organizacijos tikslais, komandiniu darbu ir organizacijos tobulinimo galimybėmis (11); draugiški santykiai su kolegomis ne darbo metu (šventès, gimtadieniai, išvykos ir kt.) 
(11); objektyvus, teisingas ir geranoriškas vadovavimas (10); puiki darbo atmosfera, emocijų ir nuotaikų valdymas, draugiški kolegų tarpusavio santykiai (10); domejjimasis darbuotojo profesinio ir asmeninio tobulejjimo poreikiais, galimybių padèti darbuotojams igyvendinti savo siekius paieška (9); galimybė mokytis ir tobulèti (seminarai, konferencijos, kvalifikacijos tobulinimo kursai, mokymai, dalijimasis patirtimi ir kt.) (9); galimybė būti pripažintam ir palaikomam (ne tik kaip darbuotojui, bet ir kaip asmeniui) (9); objektyvūs veiklos rezultatų vertinimo, skatinimo ir atlyginimo būdai (9).

Pasak S. P. Robbins (2006), organizaciją galima apibūdinti tais pačiais žodžiais kaip ir žmogų: drangiška, nelanksti, šilta, konservatyvi ar novatoriška. Be abejonès, vienas ar kitas organizacijos bruožas daro didžiulę įtaką žmonių, dirbančių joje, nuostatoms ir veiksmams. Tai patvirtina ir respondentų teiginiai: „Aplinka be itampos, kolegu palaikymas, skatina, motyvuoja (15); „Darbui įkvepia vadovų geranoriškumas, palaikymas“ (1); , Labiausiai motyvuoja galimybė realizuoti save pagal savo gebejjimų lygi, < ..> siekti savo tikslų“ (12); „, Turiu galimybę mokytis, augu kaip asmenybẻ jaučiu profesinị pasitenkinimą“ (3).

Tyrimo rezultatai atskleidè ir tai, kad socialinių darbuotojų veiklai nemažai įtakos turi aplinkos veiksniai, kurie nèra visiškai teigiami ir darnūs (kintančios nuostatos). Net dẻl tų pačių anksčiau minètų aplinkos elementų socialinių darbuotojų nuostatos skiriasi: pasigendama konstruktyvios grịžtamosios informacijos apie sèkmingą veiklą (7); socialiniams darbuotojams trūksta vadovų palaikymo, padrąsinimo, pripažinimo(7); „Ǐ̌lieka baimè, įtampa vadovų atžvilgiu“ (10); „Trūksta darnesnio kolektyvo santykių, komandinio darbo, vienas kito palaikymo“ (12); „Iškilus problemai ar nesusipratimams su kitais specialistais, ịstaigomis (...) turi išsikovoti savo tiesą“ (11); „Ribotos galimybès mokytis toliau ir tobulèti“ „Trūksta seminarų, kursų, galimybių dalyvauti konferencijose“ (4); „Kartais kolektyvinị darbą trukdo kitų darbuotojų nenoras visapusiškai atsiduoti darbui“ (2); „Menkos profesinès karjeros galimybès" (6) ir kt.

Remiantis motyvacijos sistemų teorijos autoriaus M. Fordo (1992) nuomone, nuostatos dẻl savo gebejjimų ir aplinkos padeda arba trukdo žmonėms siekti keliamų tikslų, turi ịtakos jų motyvacijai. Tyrimo dalyvių prašyta apibendrinti savo nuostatas dèl gebejjimų ir aplinkos, pažymint tik vieną jiems tinkamiausią atsakymą žemiau pateiktoje lentelejje. Tyrimo rezultatai pateikti 4 lentelejje. 
4 lentele. Modelių, susijusių su socialinių darbuotojų nuostatų dèl savo gebejjimų ir aplinkos, raiška

\begin{tabular}{|c|c|c|c|}
\hline \multirow[t]{2}{*}{ Nuostata dèl aplinkos } & \multicolumn{3}{|c|}{ Nuostata dèl gebèjimų ir ją atitinkantis modelis } \\
\hline & Stipri & Kintanti & Silpna \\
\hline Teigiama & $\begin{array}{l}\text { Tvirtos } \\
\text { (tvirtas - 10) }\end{array}$ & Vidutiniška (kuklus) & Netvirta (trapus) \\
\hline Neutrali (kintama) & $\begin{array}{l}\text { Tvirtos } \\
(\text { atkaklus - 1) }\end{array}$ & $\begin{array}{l}\text { Vidutiniška } \\
\text { (silpnas }-4, \\
\text { pažeidžiamas) }\end{array}$ & $\begin{array}{l}\text { Netvirta } \\
(\text { abejojantis }-1)\end{array}$ \\
\hline Neigiama & $\begin{array}{l}\text { Abejojama } \\
\text { (susitaikantis) } \\
\text { arba priešinamasi } \\
\text { (priešiškas) }\end{array}$ & $\begin{array}{l}\text { Vidutiniška } \\
\text { (nusivylęs) }\end{array}$ & $\begin{array}{l}\text { Silpna } \\
\text { (beviltiškas) }\end{array}$ \\
\hline
\end{tabular}

Tyrimo rezultatai atskleidè socialinių darbuotojų nuostatas dèl savo gebejjimų ir aplinkos, kurios sukuria skirtingus motyvacijos modelius. 4 lentelejje pateikti duomenys rodo, kad didžioji dauguma (10) socialinių darbuotojų yra tvirto motyvacijos modelio atstovai, turintys aiškų suvokimą, tvirtus ịsitikinimus, teigiamus tikslus ir požiūrị ị savo profesinę veiklą (Ford, 1992; Lemme, 2003).

Vienas socialinis darbuotojas pasižymi atkaklaus motyvacijos modelio charakteristikomis: turi didelę motyvuojančią galią, gebejjimą įveikti provokuojančias ar stresines aplinkybes, iškylančias profesinėje veikloje. Keturi socialiniai darbuotojai priskiria sau silpnos motyvacijos modelio požymius: gebẻjimą adekvačiai funkcionuoti tik tada, kai sekasi, ir neutralia nuostata dèl emocinès, instrumentinès, informacinès paramos bei vertinimo, galimų nerimo ir baimès simptomų, atsargaus požiūrio siekiant tikslo (Ford,1992). Iš aplinkos ir konteksto nesitikima pagalbos ar paramos. Motyvacija šiuo atveju yra silpna. Tokiais atvejais gali būti sunku sutelkti pastangas net siekti labai trokštamų rezultatų (pvz., „Tik stebuklas gali mane išgelbèti“; „Aš žinau, kad nieko iš to neišeis“). Asmuo žino, kad jam stinga žinių, gebejjimų, praktinių ịgūdžių, kurie būtini profesinei veiklai (Kavaliauskienè, 2001; 2013). Vienas socialinis darbuotojas abejoja savo motyvacija, kurios reikia, siekiant sèkmingos profesinès veiklos. Jis abejoja ir dèl palankios darbo aplinkos bei galimybės sulaukti pagalbos sudètingose profesinès veikos situacijose. (Ford, 1992). 


\section{Išvados}

Vykstant intensyviai socialinio darbo profesionalizacijai ieškoma šaltinių, kurie suteiktų socialiniam darbuotojui galimybę išreikšti save profesinèje veikloje ir patirti savo veiklos socialinị vertingumą. Atsižvelgiant ị tai tikslinga tirti socialinio darbuotojo motyvaciją skatinančius veiksnius, tarp kurių - nuostatos, kaip vienas svarbiausių motyvacijos darinių.

1. Tyrimas atskleidè, kad socialinių darbuotojų nuostatos dèl gebejjimo nustatyti paslaugos klientui poreiki ir teikti socialines paslaugas yra tvirčiausios ir pozityviausios. Jie tiki turį tokių gebėjimų. Tuo tarpu nuostatos dèl paslaugos teikimo klientui planavimo ne tokios tvirtos. Manoma, kad šis socialinio darbo proceso etapas yra gana sudètingas, tam reikia išsamesnių teorinių žinių ir praktinės veiklos patirties.

2. Nevienareikšmiškos socialinių darbuotojų nuostatos dèl darbo aplinkos: profesinès karjeros galimybių, konstruktyvios grịžtamosios informacijos, kad veikla sèkminga, vadovų palaikymo, padrąsinimo, pripažinimo, skatinimo už ryškius darbo rezultatus, galimybės mokytis ir tobulèti.

3. Remiantis atlikto tyrimo duomenimis, išskirti keturi motyvacijos modeliai, su kurių apraiškomis tapatina save socialiniai darbuotojai (tvirtas, atkaklus, silpnas, abejojantis).

Socialiniai darbuotojai teigiamai vertino tyrimą dèl savo gebejjimų ir aplinkos nuostatų, pripažindami, kad profesinè veikla (kaip reta) tampa minčių ir apmąstymų objektu: skatina pažinti visas profesijos aplinkybes (subjektyvias ir objektyvias), padeda tobulèti profesine prasme, kritiškai pažvelgti ị savo pačių profesinès veiklos interpretavimą, suprasti savo profesinès veiklos sėkmès / problemų šaltinius.

\section{Literatūra}

Covey, S. R. (2007). 8-asis iprotis. Tobulybès link. Vilnius: Alma littera.

Dirgèlienè, I. (2010). Eukaciniai aspektai socialiniame darbe: bendruomeninio igalinimo patirtis. Acta Paedagogica Vilnensia, Nr. 25, p. 172-180.

Dromantaite, A. (2012). Pasitenkinimo karjera veiksniai. Socialinis darbas. Mokslo darbai, Nr. 11 (2), p. 289300 .

Furnham, A. (1994). Personality at Work. London and New York Routledge.

Gargfield, Ch. (1986). Peak performers. The New Heroes in business. London: Hutchinson Business.

Gustaitienė, L., Pranskevičienė, A., Bukšnytė-Marmienė, L. ir kt. (2014). Darbuotojo gerovè ir pozityvi darbo aplinka: integruotas teorinis modelis. Organizacijų vadyba: sisteminiai tyrimai, p. 37-53.

Johnson, L. C. (2001). Socialinio darbo praktika, bendrasis požiūris. Vilnius: VU Specialiosios psichologijos laboratorija.

Jovaiša, L. (2007). Enciklopedinis edukologijos žodynas. Vilnius: Gimtasis žodis.

Jovaiša, L. (2009). Gyvenimo sèkmès ugdymas. Vilnius. Agora.

Kavaliauskienė, V. (2001). Pedagoginis pašaukimas ir jo ugdymas. Klaipėda. Klaipèdos universiteto leidykla.

Kavaliauskienė, V. (2008). Socialinio darbuotojo asmenybès savybės - santykio su profesija išraiška. Soter, Nr. 26 (54), p. 87-102. 
Kavaliauskienė, V. (2010). Refleksijos kultūra - socialinio darbuotojo profesinès veiklos raiškos aspektas. Acta Paedagogica Vilnensia, Nr. 25, p. 150-171.

Kavaliauskienè, V. (2013). Socialinių darbuotojų nuostatų dèl savo gebejjimų ir aplinkos raiška profesinèje veikloje. Andragogika, Nr. 1 (4), p. 187-197.

Laužackas, R. (2005). Profesinio rengimo terminų aiškinamasis žodynas. Kaunas: Vytauto Didžiojo universiteto leidykla.

Kiaunytė, A. (2008). Pokyčius patiriantys socialiniai darbuotojai: supervizijos taikymo galimybė. Socialinis darbas, Nr. 7 (2), p. 119-130.

Lemme, B. H. (2003). Suaugusiojo raida. Vilnius: Poligrafija ir informatika.

Myers, D. G. (2008). Socialine psichologija. Vilnius: Poligrafija ir informatika.

Šinkūnienè, J. R., Katkonienè, A. (2010). Socialinių darbuotojų profesinès veiklos motyvacijos veiksniai. Socialinis darbas, Nr. 9 (1), p. 64-73.

Robbins, S. P. (2006). Organizacinès elgsenos pagrindai. Vilnius: Poligrafija ir informatika.

Samoilova, V. A. (2007). Socialinis darbas, profesinès veiklos juvadas. Vilnius: VU Specialiosios psichologijos laboratorija.

Šorytė, D., Pajarskienė, B. (2014). Darbuotojų gerovė ir ją skatinantys psichosocialinės darbo aplinkos veiksniai. Visuomenés sveikata, Nr. 2 (65), p. 9-20.

\section{BELIEFS AS A FACTOR TO INCREASE THE MOTIVATION OF SOCIAL WORKER'S PROFESSIONAL ACTIVITY}

\section{Vanda Kavaliauskienė, Edita Nikolajenko}

\section{Summary}

The changing social reality poses new challenges to social work profession drawing attention to human capital - personal qualities, its understanding and purposive application in the process of professional activity. Fast professionalization of social work reflects the importance of professional potential of social worker as the major member of this process and this importance is expressed through the professional activity by the level of action. Acknowledging the role of motivation in social work, the personal position of social worker is especially important, as it is expressed by individual's attitude towards personal skills and environment which can influence the professional behaviour, strengthen / weaken motivation or help / disturb the expressing of personal creative potential. The object of the research is the beliefs as a factor to increase the motivation of social worker's professional activity. The aim of the research is to give practical substantiation to the beliefs as a factor to increase the motivation of social worker's professional activity. The methodological basis of the research is the Concept of Effective Functioning (Motivational Systems Theory, Ford, 1992) the aspect of capability beliefs (personal agency beliefs) where capability beliefs are evaluation of whether one has the personal skills needed to function effectively, and context beliefs are evaluations whether one has the responsive environment needed to support effective functio- 
ning. Trying to realize the opportunities for satisfying personal needs through work activity, attention is concentrated to harmony between person and environment. The basis and the participants of the research. The research took place in spring of 2017, in different social institutions: Social Services Centre, Family and Child Welfare Centre, Homeless Shelter, Centre for People with Disabilities, Centre of Special Education, and Caritas Care Home. The participants in the research were social workers from the mentioned social institutions having experience in social work practice able to provide information corresponding the research tasks. The research into the social worker's capability and context beliefs was based on the following methods: on a talk- interview, with an attempt made to get a text, on the basis of which the participants' beliefs could be perceived; interpretation methods - content-analysis that revealed the reality of social work practice in terms of the mentioned beliefs. The talk - interview was used to gain factual information about social worker's capability beliefs related to the main elements of problem solving process: assessment of the client's need or concern that is the source of the problem; developing the plan of action; implementation of the plan / providing services to the client, and evaluation of provided services. To research the social worker's context beliefs construct embracing essential factors characteristic to social organizations was made. Among them: objective, supportive management; positive relations with leaders, colleagues; adequate climate in the organization; emotional well-being; occupational development/career prospects; enabling performance feedback; provision of necessary resources, etc. Research conclusions. Social worker's capability and context beliefs are very important instruments creating preconditions for stable, consistent, and purposeful professional activity. Knowing one's strengths and weaknesses, beliefs in one's personal efficacy skills and occupational environment are the factors that lay grounds for a certain level of motivation in social work practice. The research called social workers' attention to their capability and occupational context, revealed the resources for productive activity and stimulated personal interpretations of their professional performance. The research findings revealed that social workers have strong and positive beliefs relating to the assessment of the client's need or concern and providing services to the client. Beliefs relating to their skills for planning the ways to solve the problem appeared to be rather moderate. This problem solving step is considered as complicated, requiring deeper and broader theoretical knowledge and good practice. The research data revealed four patterns of social workers' motivation: robust (10 respondents) - "strong and firm in purpose or outlook"; modest (4 respondents) "placing a moderate estimate on one's abilities"; tenacious (1) - "suggests strength in dealing with challenges and obstacles"; self-doubting (1) - "having a lack of faith in one's chances for success" (Ford, 1992). 